\title{
Vertical transmission and COVID-19: a scoping review
}

\author{
Transmissão vertical e COVID-19: revisão de escopo \\ Transmisión vertical y COVID-19: revisión del alcance
}

\section{Karoline Faria de Oliveira \\ ORCID: 0000-0002-7941-5852 \\ Jacqueline Faria de Oliveira" \\ ORCID: 0000-0002-2829-1837 \\ Monika Wernet ${ }^{\text {II }}$ \\ ORCID:0000-0002-1194-3261 \\ Marina Carvalho Paschoini' ORCID:0000-0003-2218-4747 \\ Mariana Torreglosa Ruiz ORCID:0000-0002-5199-7328}

'Universidade Federal do Triângulo Mineiro. Uberaba, Minas Gerais, Brazil.

"Universidade Federal do Triângulo Mineiro, Hospital de Clínicas. Uberaba, Minas Gerais, Brazil.

I' Universidade Federal de São Carlos. São Carlos,

São Paulo, Brazil.

How to cite this article:

Oliveira KF, Oliveira JF, Wernet M, Paschoini MC, Ruiz MT. Transmission vertical and COVID-19: scoping review. Rev Bras Enferm. 2021;74(Suppl 1):e20200849. https:// doi.org/10.1590/0034-7167-2020-0849

Corresponding author:

Mariana Torreglosa Ruiz

E-mail: marianatorreglosa@hotmail.com

EDITOR IN CHIEF: Dulce Barbosa ASSOCIATE EDITOR: Ana Fátima Fernandes

Submission: 07-27-2020 Approval: 12-06-2020

\begin{abstract}
Objective: Analyze available evidence related to SARS-CoV-2 infection and vertical transmission Methods: Scoping review, according to the Joanna Briggs Institute and PRISMA-SCR Searches were conducted in five electronic databases to find publications about coronavirus infection and vertical transmission. Data were extracted, analyzed and synthesized by three independent researchers using a descriptive approach. Results: The search resulted in 76 publications. After selective steps, 15 articles - retrospective descriptive or case studies - were analyzed, all in English. In order to track the infection, specimens were collected from neonates through nasal swabs and C-reactive protein from breast milk, cord blood, amniotic fluid, placenta and vaginal secretion was analyzed. A small percentage of neonates tested positive for COVID-19, but these cases were not attributed to vertical transmission. Conclusion: Vertical transmission could not be demonstrated. Research protocol registered with the Open Science Framework (https://osf.io/fawmv)

Descriptors: Infectious Disease Transmission, Vertical; Coronavirus Infections; Review; Infant Newborn; Obstetric Nursing.
\end{abstract}

\section{RESUMO}

Objetivo: analisar as evidências disponíveis acerca da temática infecção pelo SARS-CoV-2 e transmissão vertical. Métodos: Revisão de escopo, conforme o Institute Joanna Briggs e o PRISMA-ScR. Foram feitas buscas em cinco bases de dados eletrônicas de publicações sobre a temática infecção pelo coronavírus e transmissão vertical. Os dados foram extraídos analisados e sintetizados por três pesquisadores independentes de forma descritiva. Resultados: A busca resultou em 76 publicações. Após etapas seletivas, 15 artigos foram analisados, todos no idioma inglês, descritivos retrospectivos ou estudos de casos. Para rastreamento da infecção, foram adotadas a coleta de swab nasal no neonato e a análise de proteína C-reativa do leite materno, do sangue do cordão, do líquido amniótico, da placenta e da secreção vaginal. Houve pequena porcentagem de neonatos que testaram positivo para COVID-19, porém esses casos não foram atribuídos à transmissão vertical. Conclusão: A transmissão vertical não pôde ser comprovada. Protocolo de pesquisa registrado na Open Science Framework (https://osf.io/fawmv).

Descritores: Transmissão Vertical de Doença Infecciosa; Infecções por Coronavírus; Revisão; Recém-Nascido; Enfermagem Obstétrica.

\section{RESUMEN}

Objetivo: Analizar las evidencias disponibles sobre infección por SARS-CoV-2 y transmisión vertical. Métodos: Revisión de alcance, conforme el Institute Joanna Briggs y PRISMA-ScR. Se realizó búsqueda en cinco bases de datos digitales de publicaciones sobre la temática infección por coronavirus y transmisión vertical. Datos extraídos, analizados y sintetizados descriptivamente por tres investigadores independientes. Resultados: La búsqueda rescató 76 publicaciones. Luego de etapas de selección, 15 artículos fueron analizados, todos en inglés; descriptivos, retrospectivos o estudios de caso. Para rastrear la infección se adoptaron la recolección de swab nasal en el neonato y el análisis de proteína C reactiva de la leche materna, sangre del cordón, líquido amniótico, placenta y secreción vaginal. Hubo un pequeño porcentaje de neonatos cuyos tests dieron positivo de COVID-19, aunque tales casos no fueron atribuidos a la transmisión vertical. Conclusión: La transmisión vertical no pudo ser comprobada. Protocolo de investigación registrado en Open Science Framework (https://osf.io/fawmv).

Descriptores: Transmisión Vertical de Enfermedad Infecciosa; Infecciones por Coronavirus; Revisión; Recién Nacido; Enfermería Obstétrica. 


\section{INTRODUCTION}

Data from the World Health Organization (WHO) from early July 2020 showed more than 10 million cases of infection by SARS-CoV-2 (which causes COVID-19) and 500,000 deaths ${ }^{(1)}$. The virus, first detected in China in late December 2019, spread globally and, on March 11, 2020 WHO declared COVID-19 a pandemic ${ }^{(2)}$. In this context, pregnant women were classified as a risk group and considered a priority in receiving care and testing for the disease ${ }^{(3-4)}$.

Physiological changes in pregnancy predispose pregnant women to viral infections and more severe forms of COVID-19(3). The clinical manifestations of this infection are poorly described ${ }^{(3,5)}$, and this challenge is related to the pregnancy condition itself, especially the respiratory system ${ }^{(3)}$. Post-epidemic data from severe acute respiratory syndrome coronavirus 2 (SARS-CoV-2) and Middle East respiratory syndrome coronavirus (MERS-CoV) in 2012 indicated that all pregnant/puerperal women needed intubation, hospitalization in intensive care units (ICU), and presented kidney failure, with $25 \%$ progressing to death ${ }^{(3)}$.

Vertical transmission (VT) can occur through the transplacental transfer of microorganisms during pregnancy, contact with blood and vaginal secretions at the moment of delivery, and through breast milk. The placental membrane separates maternal and fetal blood, acting as a protective barrier, but some viruses and bacteria, through unknown mechanisms, are able to cross it. As widely known, maternal immunity, placental viral load ${ }^{(6)}$ and obstetrical conditions, such as preterm labor, premature rupture of amniotic membranes, low birth weight, fetal malformations, abortion and fetal death, are closely linked with and increase the risk of $\mathrm{VT}^{(7-8)}$.

In general, congenital infections are associated with a high risk of neonatal morbidity and mortality, and VT of COVID-19 is being analyzed. The teratogenic effects of fever, a common symptom of COVID-19, on newborns are unknown, but correlations have been observed between maternal pneumonia and increased premature births, low birth weight and low five-minute Apgar score ${ }^{(3)}$.

In view of this new disease, the development of this study is explained considering the new infection has been little explored in terms of its effects on pregnant women/puerperal women and newborns, and its serious outcomes in pregnant women from previous pandemics caused by respiratory viruses.

\section{OBJECTIVE}

Analyze the evidence available in the literature related to the theme of SARS-CoV-2 infection and vertical transmission.

\section{METHODS}

\section{Study design, period and site}

This is a scoping review study, an approach that is used to map evidence about a particular phenomenon and identify gaps. It differs from other types of reviews, since it involves selection criteria based on relevance to the theme/phenomenon ${ }^{(9-12)}$. The study protocol was registered with the Open Science Framework (https://osf.io/fawmv).
Data collection took place in May 2020. The investigations were performed in the following databases: US National Library of Medicine - National Institutes of Health (PubMed), Latin American and Caribbean Health Sciences Literature (Lilacs), SciVerse Scopus (Scopus), Web of Science, and Cumulative Index to Nursing and Allied Health Literature (CINAHL). These databases were selected due to the amount of indexed primary articles in the health area.

\section{Sample and inclusion and exclusion criteria}

This review included studies about coronavirus infection and VT published in 2020 in Portuguese, Spanish and English. Review studies, editorials and expert opinions were excluded. The level of evidence was not considered an exclusion criterion because it is a new theme. A total of 76 articles were identified in the five databases. The Preferred Reporting Items for Systematic Reviews and Meta-Analyses (PRISMA) methodology was adopted to systematize the process of study inclusion ${ }^{(11)}$, illustrated in Figures 1 and 2.

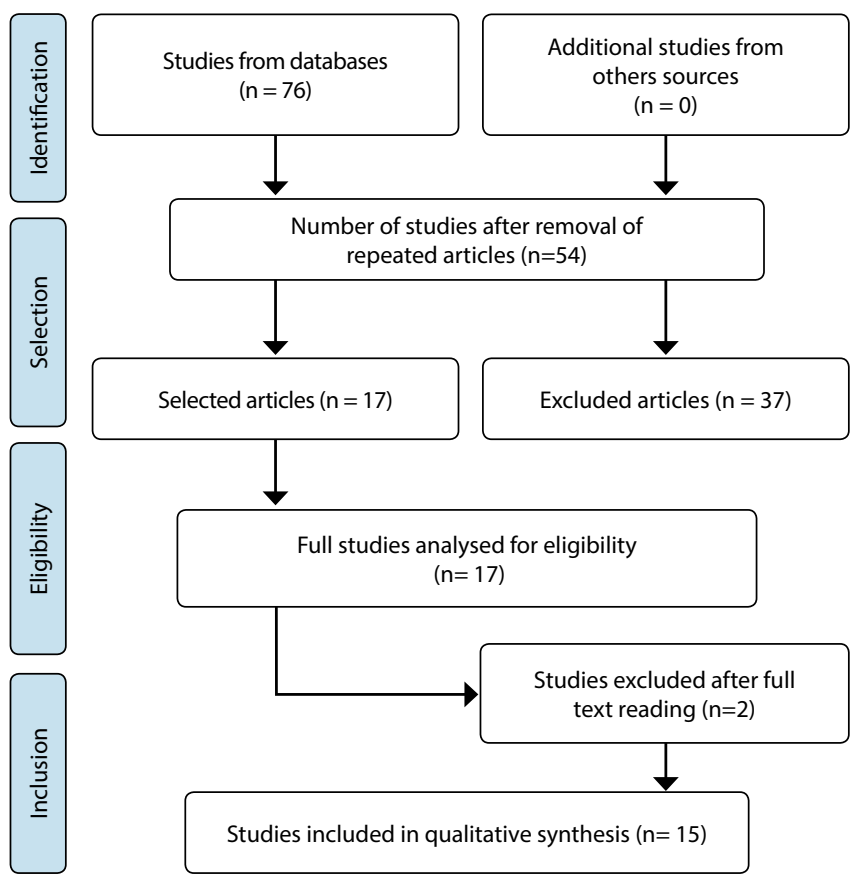

Figure 1 - Flowchart, according to the Preferred Reporting Items for Systematic Reviews and Meta-Analyses (PRISMA) methodology for study selection

\section{Study protocol}

The five steps recommended by the Joanna Briggs Institute $(\mathrm{JBI})^{(10-11)}$ were adopted to elaborate the guiding question and the search strategy, starting with the identification of the study question (What evidence is available in the literature about the theme of SARS-CoV-2 infection and VT?) and proceeding to search for relevant studies, study selection, data extraction, grouping, abstract and, finally, presentation of results. The acronym ' $P C C^{\prime}$ was used - ' $P$ ' for population (pregnant women, fetuses and neonates), 'C' for concept (VT), and ' $C$ ' for context (SARS-CoV-2/ COVID-19 infection). 


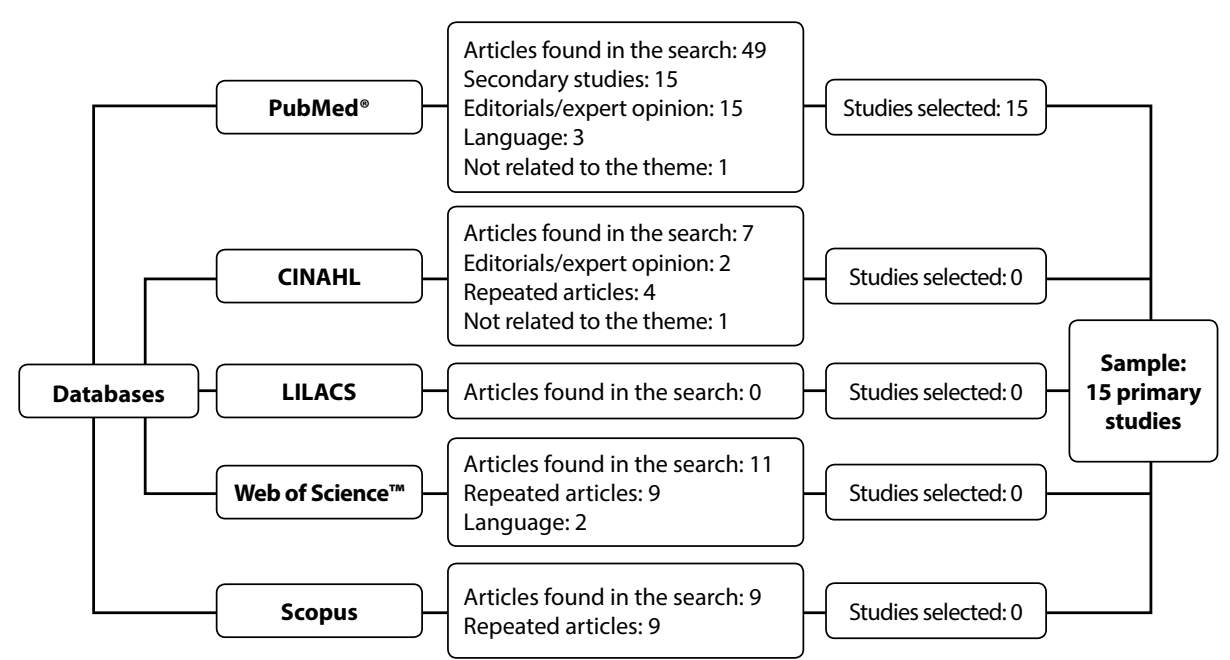

Figure 2 - Flow of article selection and reasons for exclusion from the review, according to the Preferred Reporting Items for Systematic Reviews and Meta-Analyses (PRISMA) methodology the analysis of medical records ${ }^{(17-18)}$ or case studies of pregnant women infected with COVID-19 $9^{(19-31)}$. The application of the Joanna Briggs Institute Appraisal Tools to assess the methodological quality and risk of bias helped identify a moderate risk of bias (scores between $50 \%$ and $70 \%$ ) in four studies (26.7\%) and a low risk of bias (scores above $70 \%$ ) in 11 studies (73.3\%). Among the articles with moderate risk, gaps were identified in the pregnancy history, which was incomplete, as well as studies with no laboratory evidence of maternal disease by the reference standard (polymerase chain reaction - $\mathrm{PCR}$ ). The most neglected item was the complete
Two reviewers, both with a Ph.D., independently conducted the search using controlled descriptors from Medical Subject Headings (MeSH), CINAHL Headings, and Health Sciences Descriptors, with the terms 'COVID-19;' Infectious Disease Transmission, Vertical;' and 'Coronavirus Infections' on May 26, 2020.

The descriptors were combined in different ways to broaden the search. Terminological variations in different languages and synonyms were used in the sensitive search with Boolean operators $A N D$ for the simultaneous occurrence of subjects, and $O R$, for the occurrence of respective synonyms.

\section{Data processing and analysis}

In the first stage of article selection, the title and abstract were analyzed, followed by full text reading for the final selection, with 15 studies extracted. The databases analyzed in this study were: PubMed ${ }^{\oplus}$, CINAHL, LILACS, Web of Science ${ }^{\mathrm{TM}}$, and Scopus. Repeated articles, in languages other than those defined for this study, addressing topics not related to the theme, literature reviews, qualitative studies/expert opinions/editorials were excluded.

The study information was extracted using the data collection instrument proposed and validated by Ursi and Galvão ${ }^{(13)}$, which includes identification of the article, year and place of the study, methodological characteristics, assessment of methodological rigor, level of evidence ${ }^{(14),}$ main results and discussions related to the study question ${ }^{(13)}$.To assess the methodological quality and risk of bias in the articles included, the Joanna Briggs Institute Appraisal Tools ${ }^{(15)}$ were used.

Data were synthesized by three independent researchers, and all inconsistencies found were discussed, reaching a consensus. The extracted information was tabulated for data synthesis, and the classification according to the study method was based on the concepts of scientific methodology experts ${ }^{(16)}$. The results were analyzed descriptively, with a synthesis of each primary study included in this review.

\section{RESULTS}

This study analyzed 15 scientific articles, all published in 2020 in English. They are retrospective descriptive studies based on description of maternal treatments, which were cited or ignored. Despite the methodological limitations, the articles were not excluded, as it is a recent theme. Most studies $(12 ; 80 \%)$ were conducted in China. One study was identified in Italy, Peru and Turkey each (Chart 1).

Chart 2 shows information about the type of study, delivery, clinical conditions, symptoms, diagnosis, treatment and characteristics of newborns.

Regarding the type of delivery, the rate of cesarean sections in women with COVID-19 ranged from 42.9 to $100 \%$, and the indications were maternal respiratory decompensation, fetal hypoxemia or twin pregnancy.

At hospital admission, $45.2 \%$ to $100 \%$ of the pregnant women had pneumonia. The use of oxygen through a catheter was required in $5.2 \%$ to $100 \%$ of the cases, although in six studies this variable was not evaluated. The intubation rate was $1.7 \%$ in a study with 116 pregnant women. Two cases required mechanical ventilation, but it was not described in eight studies. Two studies analyzed the percentage of ICU admission, which ranged from $6.9 \%$ to $21.1 \%$; in two case studies, intubated pregnant women were assisted in ICUs; however 11 studies did not assess the need for ICU hospitalization. No maternal death was reported among pregnant women with COVID-19 from assessed studies.

Regarding COVID-19 symptoms among pregnant women, the most frequent was fever ( $50.9 \%$ to $100 \%)$, followed by cough ( $26.3 \%$ to $50 \%$ ), fatigue ( $12.9 \%$ to $50 \%)$, dyspnea ( $7.8 \%$ to $50 \%$ ), and diarrhea (0.9\% to $25 \%$ ). The moment of SARS-CoV-2 infection diagnosis varied, but it was more prevalent before delivery ( $23.8 \%$ to $100 \%$ ) followed by labor admission (20\% to $64.3 \%$ ), and postpartum period (11.9\% to $30 \%$ ).

For drug treatment of the infection, prescription of antiviral ( $50 \%$ to $100 \%$ ) and antibiotic ( $94 \%$ to $100 \%$ ) agents was reported. Interferon and hydroxochloroquine were used in four and two cases, respectively. Corticosteroids were used in more serious cases or when lung maturation was required. The infection was mostly diagnosed by chest tomography $(85.7 \%$ to $100 \%)$ and PCR (52.9\% to 100\%). All pregnant women presented suggestive tomography results or laboratory confirmation. 
Chart 1 - Synthesis of selected articles $(n=15)$

\begin{tabular}{|c|c|c|c|c|}
\hline Country & Objectives & $\begin{array}{c}\text { Study design/ } \\
\text { participants }\end{array}$ & Methodological procedures and outcomes & $\begin{array}{l}\text { Risk of bias } \\
(J B I)^{*(14)}\end{array}$ \\
\hline 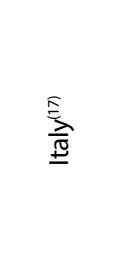 & $\begin{array}{l}\text { Assess the type of } \\
\text { delivery and immediate } \\
\text { neonatal outcomes in } \\
\text { women infected with } \\
\text { COVID-19 before or up to } \\
36 \text { hours after delivery. }\end{array}$ & $\begin{array}{l}\text { Cross- } \\
\text { sectional } \\
\text { study with } \\
\text { retrospective } \\
\text { data } / \mathrm{n}=42\end{array}$ & $\begin{array}{l}\text { Medical records of } 42 \text { binomials were reviewed. Three neonates had SARS-CoV-2 } \\
\text { (COVID-19) infection. Two were on exclusive breastfeeding with mothers without } \\
\text { a mask who were diagnosed with postpartum COVID-19; the other one was } \\
\text { born via vaginal delivery and separated from the mother immediately after birth } \\
\text { because the mother presented postpartum hemorrhage. In this case, the newborn } \\
\text { presented diarrhea on the first and third days of life and respiratory symptoms. The } \\
\text { infant was taken to the ICU and remained on MV for one day. The infant presented } \\
\text { positive PCR only on the seventh day of life. }\end{array}$ & $89 \%$ \\
\hline 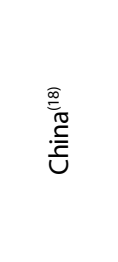 & $\begin{array}{l}\text { Assess the clinical } \\
\text { characteristics and results } \\
\text { of pregnancies of women } \\
\text { with pneumonia due } \\
\text { to COVID-19 and the } \\
\text { potential risk of VT. }\end{array}$ & $\begin{array}{l}\text { Cross- } \\
\text { sectional } \\
\text { study with } \\
\text { retrospective } \\
\text { data (series of } \\
\text { case studies)/ } \\
\mathrm{n}=116\end{array}$ & $\begin{array}{l}\text { Records of pregnant women with pneumonia due to COVID-19 from } 25 \text { hospitals } \\
\text { were analyzed. Eight cases occurred before } 24 \text { gestational weeks and, of these, } \\
\text { one resulted in spontaneous abortion (infection with fever at week 5). All cases } \\
\text { had normal fetal morphology (on ultrasound). Of } 10 \text { cases between } 24 \text { and } 33 \\
\text { weeks, } 20 \% \text { progressed to preterm labor, with one pregnancy at } 28 \text { weeks and } \\
\text { another twin pregnancy at } 31 \text { weeks. Of } 24 \text { cases between } 34 \text { and } 36 \text { weeks, } 79 \% \\
\text { progressed to preterm delivery and } 27.3 \% \text { to premature rupture of membranes. No } \\
\text { VT was found in the PCR result of newborns. }\end{array}$ & $50 \%$ \\
\hline 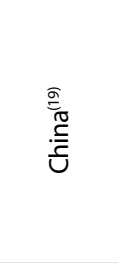 & $\begin{array}{l}\text { Assess the clinical } \\
\text { characteristics of a } \\
\text { pregnant woman with } \\
\text { COVID-19 and the } \\
\text { pregnancy outcomes. }\end{array}$ & $\begin{array}{l}\text { Case study/ } \\
\quad \mathrm{n}=1\end{array}$ & $\begin{array}{l}\text { Description of a case study of a pregnant woman, primigravida, } 22 \text { years old, } 38 \\
\text { weeks of pregnancy. During labor, she did not present any identifiable symptoms } \\
\text { of COVID-19. Fetal movements were present, vital parameters were normal, fetal } \\
\text { morphology ultrasound with normal development. She had a history of contact } \\
\text { with people with COVID-19 (husband and sister). She was maintained in isolation } \\
\text { and oxygen therapy was administered in a catheter ( } 2 \mathrm{~L} / \text { minute) due to the } \\
\text { diagnosis of pneumonia. She had fever at day } 2 \text { after delivery, with improvement } \\
\text { and discharge at day } 25 \text {. No VT was found in the PCR result of the newborn. }\end{array}$ & $100 \%$ \\
\hline 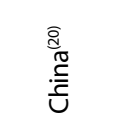 & $\begin{array}{l}\text { Present and discuss the } \\
\text { case of a newborn whose } \\
\text { mother was diagnosed } \\
\text { with COVID-19. }\end{array}$ & $\begin{array}{l}\text { Case study/ } \\
\quad \mathrm{n}=1\end{array}$ & $\begin{array}{l}\text { Description of the case study of a pregnant woman, primigravida, } 25 \text { years old. } \\
\text { Infection acquired in the third trimester of pregnancy. No VT was found in the PCR } \\
\text { result of the newborn. }\end{array}$ & $87.5 \%$ \\
\hline $\begin{array}{l}\overline{\bar{a}} \\
\frac{2}{\alpha} \\
\alpha\end{array}$ & $\begin{array}{l}\text { Describe the case of a } \\
\text { pregnant woman with } \\
\text { COVID-19 infection } \\
\text { whose newborn was } \\
\text { positive for COVID-19. }\end{array}$ & $\begin{array}{l}\text { Case study/ } \\
\quad \mathrm{n}=1\end{array}$ & $\begin{array}{l}\text { Description of the case of a pregnant woman, third pregnancy, no prior abortion, } \\
41 \text { years old, } 33 \text { weeks of pregnancy, admitted with respiratory failure. She had a } \\
\text { history of gestational diabetes, use of insulin and metformin, and obesity. Partner } \\
\text { and two children with COVID-19 symptoms for } 14 \text { days. The infant was born via } \\
\text { cesarean delivery with } 2.970 \mathrm{~g} \text {, Apgar } 6 \text { and } 8 \text { at day } 1 \text { and } 5 \text {, respectively. The } \\
\text { newborn had positive PCR, } 16 \text { and } 48 \text { hours postpartum. On the sixth day of life, } \\
\text { the newborn developed cough and respiratory distress, which were resolved with } \\
\text { nasal oxygen therapy (catheter). }\end{array}$ & $87.5 \%$ \\
\hline 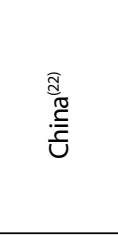 & $\begin{array}{l}\text { Report the clinical } \\
\text { characteristics of } \\
\text { newborns whose } \\
\text { mothers were infected } \\
\text { with SARS-CoV-2. }\end{array}$ & $\begin{array}{l}\text { Case study/ } \\
\quad \mathrm{n}=7\end{array}$ & $\begin{array}{l}\text { Description of seven case studies of mothers infected with SARS-CoV- } 2 \text { during } \\
\text { pregnancy, with } 85.7 \% \text { diagnosed one to six days before delivery. All infants were } \\
\text { born via cesarean delivery and had an Apgar score over } 8 \text { in the fifth minute of } \\
\text { life; } 57.1 \% \text { had between } 36 \text { and } 37 \text { gestational weeks. The neonates were taken to } \\
\text { the ICU for respiratory isolation, and two required non-invasive ventilation with } \\
\text { CPAP due to prematurity. All PCR tests were negative, and the newborns were } \\
\text { discharged in good condition. }\end{array}$ & $50 \%$ \\
\hline 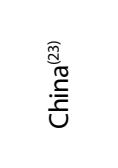 & $\begin{array}{l}\text { Assess the clinical } \\
\text { characteristics of } \\
\text { neonates whose } \\
\text { mothers had SARS-CoV-2 } \\
\text { infection. }\end{array}$ & $\begin{array}{l}\text { Case study/ } \\
\quad \mathrm{n}=19\end{array}$ & $\begin{array}{l}\text { Neonates had an average gestational age of } 38 \text { weeks; } 94.7 \% \text { of deliveries were } \\
\text { via cesarean section, and all newborns were separated from their mothers } \\
\text { immediately after delivery. No clinical and/or laboratory evidence of SARS-CoV-2 } \\
\text { infection was found in the newborns. The newborns were separated from their } \\
\text { mothers immediately after delivery to avoid contamination. }\end{array}$ & $50 \%$ \\
\hline 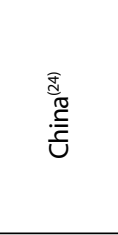 & $\begin{array}{l}\text { Report the case of a } \\
\text { convalescent pregnant } \\
\text { woman diagnosed with } \\
\text { COVID-19 infection } 37 \\
\text { days before the delivery, } \\
\text { in the third trimester of } \\
\text { pregnancy. }\end{array}$ & $\begin{array}{l}\text { Case study/ } \\
\quad \mathrm{n}=1\end{array}$ & $\begin{array}{l}\text { A case study of a newborn whose mother was diagnosed with COVID-19 in the } 33^{\text {rd }} \\
\text { week of pregnancy. PCR and immunoglobulin (IgM and lgG) tests of the newborn } \\
\text { placenta were negative. Anatomopathological examination of the placenta was } \\
\text { also negative for COVID-19. }\end{array}$ & $75 \%$ \\
\hline 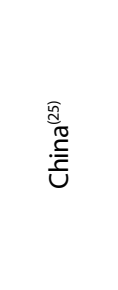 & $\begin{array}{l}\text { Identify all newborns } \\
\text { infected with COVID-19 } \\
\text { and describe their clinical } \\
\text { characteristics, treatment, } \\
\text { results and potential } \\
\text { transmission. }\end{array}$ & $\begin{array}{l}\text { Case study/ } \\
\qquad \mathrm{n}=4\end{array}$ & $\begin{array}{l}\text { Four newborns were assessed, aged between } 30 \text { hours and } 17 \text { days of life, } \\
\text { diagnosed with COVID-19, whose mothers had a confirmed diagnosis of COVID-19 } \\
\text { (clinical, laboratory and imaging tests). Retrospective data from medical records } \\
\text { were analyzed. Of the four newborns diagnosed with the infection, two had fever, } \\
\text { one had dyspnea, one had cough and one was asymptomatic. The newborns } \\
\text { received supportive treatment, not requiring intensive care or MV. The newborns } \\
\text { were discharged between } 16 \text { and } 30 \text { days of hospitalization. It was not possible } \\
\text { to rule out the risk of infection transmitted by health professionals during the } \\
\text { hospitalization period. }\end{array}$ & $50 \%$ \\
\hline
\end{tabular}




\begin{tabular}{|c|c|c|c|c|}
\hline Country & Objectives & $\begin{array}{c}\text { Study design/ } \\
\text { participants }\end{array}$ & Methodological procedures and outcomes & $\begin{array}{l}\text { Risk of bias } \\
(\mathrm{JBI}) *(14)\end{array}$ \\
\hline 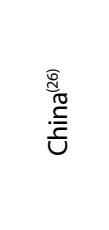 & $\begin{array}{l}\text { Describe the clinical } \\
\text { case of four newborns of } \\
\text { mothers diagnosed with } \\
\text { COVID-19 infection. }\end{array}$ & $\begin{array}{c}\text { Case study/ } \\
n=4\end{array}$ & $\begin{array}{l}\text { Four cases of newborns were described; their mothers had COVID-19, so they } \\
\text { were separated from their mothers immediately after delivery. Two had skin } \\
\text { rashes of unknown etiology and one had facial ulceration, which disappeared } \\
\text { spontaneously. One infant developed tachypnea and MV was required for } \\
\text { three days, with discharge on the sixth day of life. Skin rash was considered a } \\
\text { consequence of maternal inflammatory toxin. No VT was found in the PCR result of } \\
\text { the newborns. }\end{array}$ & $75 \%$ \\
\hline 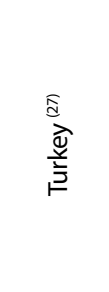 & $\begin{array}{l}\text { Report the case of } \\
\text { positive findings from } \\
\text { pulmonary ultrasound } \\
\text { compatible with } \\
\text { COVID-19 in a woman } \\
\text { with a negative PCR } \\
\text { result. }\end{array}$ & $\begin{array}{c}\text { Case study/ } \\
\qquad n=1\end{array}$ & $\begin{array}{l}\text { A case study a pregnant woman, } 35 \text { weeks pregnant, who had no fever, with } \\
\text { cough, dyspnea and nausea, and negative result in the PCR test. She had a } \\
\text { thalassemia trait, not anemic. Her condition was worse two days after the negative } \\
\text { result in the PCR test. The pulmonary ultrasound test showed an increase in the } \\
\text { thick lines of the lung (posterior basal segments). She refused a new exam. Two } \\
\text { days later, dyspnea was worse, with reduced fetal movement and lower limb } \\
\text { edema. CT and new oropharyngeal swab tests were performed. The patient's CT } \\
\text { was consistent with viral infection, with positive swab test for SARS-CoV-2 infection. } \\
\text { No VT was found in the PCR result of the newborn. }\end{array}$ & $87.5 \%$ \\
\hline 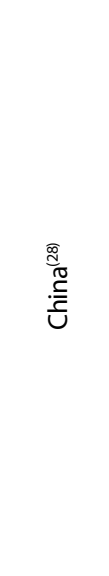 & $\begin{array}{l}\text { Report two clinical cases } \\
\text { of newborns whose } \\
\text { mothers were infected } \\
\text { with SARS-CoV-2 in } \\
\text { the third trimester of } \\
\text { pregnancy. }\end{array}$ & $\begin{array}{c}\text { Case study/ } \\
n=2\end{array}$ & $\begin{array}{l}\text { Case 1: second pregnancy, } 34 \text { years, } 37 \text { weeks, no comorbidities. The patient } \\
\text { presented nasal congestion and abdominal rash, exposed to COVID-19. On the } 11^{\text {th }} \\
\text { day of infection, the infant was born with } 3.400 \mathrm{~g} \text {, Apgar } 9 \text { and } 10 \text { on the } 1^{\text {st }} \text { and } 5^{\text {th }} \\
\text { minutes of life, respectively, and was separated from the mother at birth. On the } \\
3^{\text {rd }} \text { day of life, the newborn presented abdominal distension and lymphopenia. On } \\
\text { the } 4^{\text {th }} \text { day, chest CT indicated pneumonia, negative COVID-19 result in nasal swab } \\
\text { PCR, and in the specimens of umbilical cord blood, placenta, amniotic fluid, vaginal } \\
\text { secretion swab, and breast milk. The newborn presented good response with } \\
\text { antibiotic therapy and was discharged at day } 8 \text { after birth. } \\
\text { Case 2: primigravida, } 29 \text { years old, } 36 \text { weeks, no comorbidities. She presented chills, } \\
\text { fever, nasal congestion, sore throat and minor vaginal bleeding, and was released } \\
\text { after examination. Two days later, the husband received a positive result for } \\
\text { COVID-19. On the third day of symptoms, she presented positive PCR for COVID-19 } \\
\text { and suggestive CT imaging on the fifth day of symptoms. That same day, the infant } \\
\text { was born with } 2.980 \mathrm{~g} \text {, Apgar } 9 \text { and } 10 \text { in the first and fifth minutes of life, separated } \\
\text { from the mother at birth. The newborn presented pneumonia and lymphopenia } \\
\text { with good response to antibiotic therapy in two days. } \\
\text { No VT was found in the PCR result of the newborns in both cases. }\end{array}$ & $100 \%$ \\
\hline 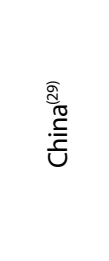 & $\begin{array}{l}\text { Report the case of a } \\
\text { neonate with COVID-19 } \\
\text { infection } 36 \text { hours after } \\
\text { birth. }\end{array}$ & $\begin{array}{c}\text { Case study/ } \\
\qquad n=1\end{array}$ & $\begin{array}{l}\text { Second pregnancy, with previous abortion, } 34 \text { years old, no comorbidities, without } \\
\text { home contacts, } 15 \text { confirmed cases of COVID-19 in the community where she lived. } \\
\text { At } 40 \text { weeks, she had vaginal bleeding and abdominal pain. She presented fever } \\
\left(37.8^{\circ} \mathrm{C}\right) \text {, chest CT suggestive of COVID-19, lymphopenia, neutrophilia and high } \\
\text { PCR level. The mother had no contact with the newborn after birth. A PCR test was } \\
\text { performed in the newborn after } 36 \text { hours of life, with a positive result. The newborn } \\
\text { was asymptomatic, but with suggestive chest CT scan. PCR was negative on day 14, } \\
\text { the newborn was discharged on day } 15 \text {. }\end{array}$ & $87.5 \%$ \\
\hline 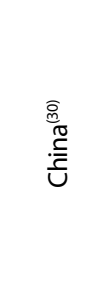 & $\begin{array}{l}\text { Describe the clinical } \\
\text { characteristics of } \\
10 \text { neonates whose } \\
\text { mothers had a diagnosis } \\
\text { of pneumonia due to } \\
\text { COVID-19. }\end{array}$ & $\begin{array}{l}\text { Case study/ } \\
\qquad \mathrm{n}=10\end{array}$ & $\begin{array}{l}\text { Mean age of mothers: } 30 \text { years. Diagnosis: one to six days of symptoms. } \\
\text { Four infants were born at term and six were premature; two were extremely } \\
\text { underweight and one was large for its gestational age. Six had respiratory distress, } \\
\text { four had gastrointestinal symptoms, two had fever, and one had high respiration } \\
\text { rate. Seven had a chest CT suggestive of COVID-19. Apgar scores ranged from } 7 \text { to } \\
10 \text { in the first minute and from } 8 \text { to } 10 \text { in the fifth minute. No antiviral agent was } \\
\text { administered to them. Five were discharged; four remained hospitalized in good } \\
\text { condition and one died due to multiple organ failure (due to prematurity). No VT } \\
\text { was found in the PCR result of the newborns. }\end{array}$ & $100 \%$ \\
\hline 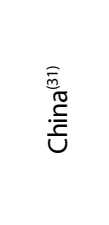 & $\begin{array}{l}\text { Assess the clinical } \\
\text { characteristics of } \\
\text { pregnant women with } \\
\text { COVID-19 and potential } \\
\text { VT. }\end{array}$ & $\begin{array}{c}\text { Case study/ } \\
n=9\end{array}$ & $\begin{array}{l}\text { All pregnant women had an infection in the third trimester. Maternal age ranged } \\
\text { from } 26 \text { to } 40 \text { years; gestational age } 36 \text { to } 39 \text { weeks and } 4 \text { days. One patient had } \\
\text { gestational hypertension and eight did not have comorbidities. All were stable } \\
\text { at the time of delivery. Most common symptoms: fever, sore throat and myalgia. } \\
\text { Two cases of fetal hypoxemia and two cases of premature rupture of membranes. } \\
\text { Samples of amniotic fluid, umbilical cord, neonatal swab and milk sample were } \\
\text { collected from six neonates with negative results in the PCR test. }\end{array}$ & $87.5 \%$ \\
\hline
\end{tabular}


Chart 2 - Characterization of studies in terms of type of delivery, clinical conditions and symptoms of pregnant women, diagnosis, treatment and characteristics of newborns

\begin{tabular}{|c|c|c|c|c|c|c|c|c|c|c|c|c|c|c|c|}
\hline \multirow{2}{*}{$\begin{array}{l}\text { Variables } \\
\text { Delivery }\end{array}$} & \multicolumn{15}{|c|}{ Reference/participants } \\
\hline & $\begin{array}{c}(17) \\
(42)\end{array}$ & $\begin{array}{c}(18) \\
(116)\end{array}$ & $\begin{array}{l}(19) \\
(1)\end{array}$ & $\begin{array}{l}(20) \\
(1)\end{array}$ & $\begin{array}{l}\text { (21) } \\
\text { (1) }\end{array}$ & $\begin{array}{l}(22) \\
\text { (7) }\end{array}$ & $\begin{array}{c}\text { (23) } \\
\text { (19) }\end{array}$ & $\begin{array}{l}(24) \\
(1)\end{array}$ & $\begin{array}{l}(25) \\
(4)\end{array}$ & $\begin{array}{l}(26) \\
(4)\end{array}$ & $\begin{array}{l}(27) \\
(1)\end{array}$ & $\begin{array}{l}\text { (28) } \\
\text { (2) }\end{array}$ & $\begin{array}{l}(29) \\
(1)\end{array}$ & $\begin{array}{c}(30) \\
(10)\end{array}$ & $\begin{array}{l}\text { (31) } \\
\text { (9) }\end{array}$ \\
\hline Vaginal & 57.1 & 14.1 & - & - & - & - & 5.3 & Yes & - & 25 & - & - & - & 30 & - \\
\hline Cesarean & 42.9 & 85.9 & Yes & Yes & Yes & 100 & 94.7 & - & 100 & 75 & Yes & 100 & Yes & 70 & 100 \\
\hline \multicolumn{16}{|c|}{ Clinical condition of pregnant women } \\
\hline Pneumonia at admission & 45.2 & 77.8 & Yes & Yes & Yes & 85.7 & 100 & Yes & - & 100 & Yes & 100 & Yes & 100 & 100 \\
\hline Oxygen therapy & 36.8 & 5.2 & Yes & Yes & Yes & - & - & No & - & 25 & Yes & - & - & - & 100 \\
\hline Intubation & - & 1.7 & No & No & Yes & - & - & No & - & - & Yes & - & - & - & No \\
\hline Hospitalization in ICU & 21.1 & 6.9 & No & No & Yes & - & - & No & - & - & Yes & - & - & - & - \\
\hline Maternal death & No & No & No & No & No & No & No & No & No & No & No & No & No & No & No \\
\hline \multicolumn{16}{|l|}{ Symptoms } \\
\hline Fever & Yes & 50.9 & Yes & Yes & Yes & Yes & 57.9 & Yes & Yes & 75 & No & 100 & Yes & 90 & 78 \\
\hline Cough & Yes & 28.4 & Yes & - & - & Yes & 26.3 & Yes & Yes & 50 & Yes & - & - & 40 & 44 \\
\hline Fatigue & - & 12.9 & Yes & Yes & Yes & - & - & - & - & 50 & - & - & - & - & 22 \\
\hline Dyspnea & Yes & 7.8 & Yes & Yes & Yes & - & 26.3 & - & - & 50 & Yes & - & - & - & 11 \\
\hline Diarrhea & Yes & 0.9 & Yes & - & - & Yes & 10.5 & - & - & 25 & - & - & - & 10 & 11 \\
\hline \multicolumn{16}{|l|}{ Diagnosis } \\
\hline Before delivery & 23.8 & 37.9 & No & Yes & No & 85.7 & 68.4 & Yes & 75 & - & Yes & 100 & - & 50 & 88 \\
\hline At admission & 64.3 & - & Yes & No & Yes & No & 10.5 & - & - & - & - & - & Yes & 20 & - \\
\hline Postpartum period & 11.9 & - & No & No & No & 14.3 & 21.1 & - & 25 & - & - & - & - & 30 & 22 \\
\hline Positive result in PCR test & Yes & 56.0 & Yes & Yes & Yes & Yes & 52.9 & Yes & 100 & 100 & Yes & 100 & Yes & 80 & 100 \\
\hline CT scan indicative of infection & - & 96.3 & Yes & Yes & Yes & 85.7 & 100 & Yes & 100 & 100 & Yes & 100 & Yes & 100 & 100 \\
\hline Amniotic fluid & - & Yes- & - & Yes- & - & Yes- & Yes- & Yes- & - & - & - & Yes- & - & - & $67(-)$ \\
\hline Cord blood & - & Yes- & - & Yes- & - & Yes- & Yes- & - & - & - & Yes- & Yes- & Yes- & - & $67(-)$ \\
\hline Breast milk & - & Yes- & Yes- & Yes- & - & - & Yes- & Yes- & - & - & Yes- & Yes- & Yes- & - & $67(-)$ \\
\hline Placenta & - & - & - & Yes- & - & - & - & Yes- & - & - & Yes- & Yes- & Yes- & - & - \\
\hline Vaginal swab & - & Yes- & - & Yes- & - & - & - & Yes- & - & - & - & Yes- & - & - & - \\
\hline \multicolumn{16}{|l|}{ Treatment } \\
\hline Antiviral & - & 54.3 & Yes & Yes & Yes & - & 31.6 & Yes & - & - & Yes & 100 & Yes & 50 & 67 \\
\hline Interferon & - & - & Yes & Yes & - & - & - & - & - & - & - & - & Yes & 10 & - \\
\hline Corticoid & - & 31.9 & No & Yes & Yes & - & No & Yes & - & - & Yes & 50 & Yes & - & - \\
\hline Antibiotic & - & 94.0 & No & Yes & Yes & - & - & - & - & - & Yes & 100 & Yes & - & 100 \\
\hline Hydroxychloroquine & - & - & - & - & Yes & - & - & - & - & - & Yes & - & - & - & - \\
\hline \multicolumn{16}{|l|}{ Neonate } \\
\hline COVID-19 infection & 7.1 & No & No & No & Yes & No & No & No & Yes & No & No & No & Yes & No & No \\
\hline Breastfeeding & 26.2 & - & No & No & No & - & No & - & 25 & No & Yes & - & No & - & - \\
\hline Oropharyngeal swab & Yes & 86 & Yes & Yes & Yes & Yes & Yes & Yes- & Yes+ & $75-$ & Yes- & Yes- & Yes+ & Yes- & Yes- \\
\hline Preterm birth & 26.2 & 21.2 & No & Yes & Yes & 57.1 & 10.5 & No & No & No & Yes & 50 & No & 60 & 44 \\
\hline Neonatal death & 0 & 0.9 & No & No & No & No & No & No & No & No & No & No & No & 10 & No \\
\hline Neonatal ICU & 7.1 & 47.0 & Yes & Yes & Yes & 71.4 & Yes & No & No & 25 & No & 50 & Yes & - & - \\
\hline
\end{tabular}

Results expressed as \%.

Notes: ICU: intensive care unit; PCR: polymerase chain reaction; COVID-19: coronavirus disease 2019.

Regarding VT, no consensus was found among the institutions regarding the collection of specimens. Most neonates were tested by PCR through a nasopharyngeal swab specimen (75\%). In a study describing four newborns of mothers with COVID-19(27), the parents of one newborn did not consent testing, as the infant was asymptomatic. Another study with 116 pregnant women ${ }^{(18)}$ did not report the reason why $14 \%$ of newborns were not tested.

In nine studies (60\%), the PCR technique was performed for viral detection in breast milk samples, eight studies (53.3\%) used PCR to test umbilical cord blood samples, and seven studies (46.7\%) used PCR to test the amniotic fluid. Five placentas were submitted to anatomopathological examination, and blood samples were collected for PCR (33.3\%). In four studies (26.7\%), vaginal discharge was collected. The failure to perform PCR tests with samples of breast milk, amniotic fluid, placental blood, umbilical cord blood, and placental anatomopathology exam was considered a study limitation. In all specimens tested, the PCR was negative for COVID-19. In a study conducted in Turkey ${ }^{(27)}$, the sample of amniotic fluid was contaminated with maternal blood and was discarded. A study that assessed nine cases in China ${ }^{(31)}$ did not show amniotic fluid sampling in $33.3 \%$ of cases, as COVID-19 was diagnosed in the postpartum period.

Regarding neonates, a study conducted in Italy ${ }^{(17)}$ with 42 pregnant women with COVID-19 showed a $7.1 \%$ infection prevalence. 
Of the three newborns who tested positive, two were on exclusive breastfeeding with their mothers without a mask, diagnosed with COVID-19 in the post-partum period. The authors attributed these cases of newborn infection to contact with the mother, and not to breastfeeding, despite unavailable data related to milk analysis. In a study conducted in Peru ${ }^{(27)}$, a newborn presented a positive result in PCR 16 and 48 hours after birth and developed respiratory distress. The newborn was not breastfed, but samples were not taken from different specimens for VT confirmation.

A Chinese study with four newborns with COVID-19 ${ }^{(25)}$ found that they did not require intensive treatment or MV and were discharged. No samples were taken from different specimens for VT confirmation, and it was not possible to rule out the risk of infection during the hospitalization period transmitted by health professionals (healthcare-associated infection - HAI). A study described the case of a newborn infected with SARS-CoV-2 36 hours after birth ${ }^{(29)}$ who had no contact with the mother after birth. In this case, samples of umbilical cord blood, placenta and breast milk were collected, and all samples were negative for COVID-19.

Adding the 219 newborns from all studies, the prevalence of neonatal infection by COVID was $4.1 \%$. The impact of infection on the occurrence of prematurity ranged from $10 \%$ to $60 \%$. Regarding admission to neonatal ICU, the rate was $7.1 \%$ to $71.4 \%$. In two Chinese studies, with one ${ }^{(19)}$ and 19 cases $^{(23)}$, neonates remained in the ICU only for isolation from other newborns and maternal contact, as they were asymptomatic and did not require intensive care.

Two neonatal deaths were described, with negative PCR for COVID-19. Deaths may have occurred due to physiological immaturity (prematurity), as they presented gestational age of 35 and 34 weeks and 5 days, respectively.

\section{DISCUSSION}

The results about VT of SARS-CoV-2 show this theme has very limited knowledge.

International recommendations state SARS-CoV-2 infection is not an indication for cesarean delivery, which must consider the clinical conditions of the pregnant woman, gestational age and fetal conditions/viability ${ }^{(3,32-33)}$, and must be assessed individually ${ }^{(34)}$. However, the results of our review showed high rates of cesarean sections in pregnant women infected with coronavirus due to maternal and/ or fetal conditions, in agreement with other studies reporting a predominance of cesarean sections, with rates from $78 \%$ to $100 \%{ }^{(35-40)}$.

At admission of pregnant women for childbirth assistance, studies reported that some of them had pneumonia. Studies indicate that $91.8 \%$ to $100 \%$ of the cases of pregnant women infected with the coronavirus developed pneumonia ${ }^{(37,41)}$. Viral pneumonia in pregnant women can lead to more severe conditions, increasing morbidity and mortality, with rates higher than those of bacterial pneumonia ${ }^{(41)}$. In cases of pneumonia due to COVID-19, hospitalization is recommended with multi- and interdisciplinary support, proper hydration (rigorous fluid balance), non-invasive monitoring, oxygen therapy, preferably in ICU with support from neonatal ICU. When maternal saturation is less than $95 \%$, early intubation and MV (or use of an extracorporeal membrane) is recommended to avoid maternal respiratory failure and fetal hypoxemia ${ }^{(3,32-33)}$.
The results of this analysis showed a wide variation in the frequency of oxygen therapy with nasal catheter and low rates of hospitalization in ICU and MV among pregnant women with the infection. In the literature, the rates of MV varied from $0-26.3 \%$ of pregnant women ${ }^{(37-38,42)}$. There are no reports of rates of oxygen therapy with catheter for comparison purposes.

The hospitalization rate of pregnant women with COVID-19 in ICU ranged from $2.7 \%$ to $34.1 \%{ }^{(37-40)}$. A study of infections by SARS-CoV coronavirus (2002-2003) showed that $25 \%$ of pregnant women required MV, and $54.5 \%$ of pregnant women with MERS-CoV (2012) required intensive support from $I C U^{(41)}$. When comparing the evidence of both coronavirus epidemics (SARS-CoV and MERS-CoV) with that of the current pandemic, lower rates of MV and admission to ICU were observed, thus COVID-19 has appeared to be less lethal(39).

Regarding drug treatment, there is still no consensus in cases of pregnant women infected with COVID-19. Recommendations suggest the combination of lopinavir/ritonavir, used in the treatment of human immunodeficiency virus (HIV) and safe drugs during pregnancy, showed positive results, especially if associated with inhalations with interferon (a protein that prevents viral replication) ${ }^{(32,43)}$. Remdesivir (antiviral), chloroquine and hydroxychloroquine (used in the treatment of malaria and autoimmune diseases) showed promising results in vitro, that is, in phase 3 trials, but cautious individualized use is recommended ${ }^{(32,42)}$.

Antibiotics are recommended in $100 \%$ of cases of pregnant women with viral pneumonia to prevent secondary bacterial infection ${ }^{(3,32,34)}$. Corticosteroids reduce viral clearance in the maternal body and should be used in cases of severe maternal hypoxemia for short periods ( 3 to 5 days) (32) $^{(2)}$ an in prematurity, for fetal lung maturation ${ }^{(43)}$. This approach must be individualized $^{(3,40)}$, as it refractorily increases blood glucose and can lead to immunosuppression ${ }^{(40)}$. There is still no consensus on the use of corticosteroids in pregnant women.

No death was described among pregnant women infected with SARS-CoV-2 in the evaluated studies, which is similar to the results of other studies ${ }^{(39,42,44)}$, in contrast to a review of cases that reported $6.4 \%$ of pregnant women infected by SARS-CoV- 2 with progression to death ${ }^{(45)}$.

Similar to the results of our review, fever was the most common symptom in pregnant women with COVID-19, ranging from $68 \%$ to $89 \%$ of all cases ${ }^{(36,38,40)}$, followed by cough with rates from $28 \%$ to $57.1 \%(37-38,40)$, and dyspnea, affecting $12 \%$ to $27 \%$ of pregnant women $^{(37-38,40)}$. One study found that $89.2 \%$ of COVID-19 diagnoses occurred before delivery; $5.4 \%$ at the time of delivery and $5.4 \%$ in the postpartum period ${ }^{(40)}$ - similar to our review in terms of pre-delivery data, but higher at delivery and postpartum period.

For diagnostic assessment, PCR testing is recommended for all symptomatic pregnant women ${ }^{(3,32-33,43)}$ and for asymptomatic pregnant women who have contacted positive people for the infection $^{(3,22-33)}$. In asymptomatic people who have contacted positive people, nasopharyngeal swab specimens should be collected $^{(3)}$, and in symptomatic pregnant women, sputum, endotracheal aspirate and/or bronchoalveolar lavage samples should be collected ${ }^{(3)}$. In addition, it highlights the need for two negative results to rule out infection ${ }^{(3)}$. Our analysis of the studies found that, in some cases, maternal PCR test was not performed, contrary to the recommendation of testing priority. 
Our review found predominant diagnoses of COVID-19 by computed tomography of the chest. Recommendations point out $C T$ is a diagnostic tool that should be associated with the PCR test, especially for cases developing pneumonia and requiring clinical monitoring ${ }^{(3,32)}$. Pregnant women undergoing $\mathrm{CT}$ scan are advised to sign a consent form, since it involves radiation. It should be clarified that radiation in $\mathrm{CT}$ of the chest varies from $0.01 \mathrm{mGy}$ to $0.66 \mathrm{mGy}$, and the radiation that causes fetal malformation is above $610 \mathrm{mGy}$, so it is considered a safe procedure ${ }^{(3)}$.

Regarding the diagnosis of potential VT, there is no consensus on sample collection. The amniotic fluid analysis identifies an intrauterine infection. Umbilical cord blood samples may indicate the transfer of maternal antibodies. Vaginal secretion swabs should be taken in cases of vaginal deliveries to assess risk associated with the type of delivery. Breast milk analysis can indicate transmission through breastfeeding ${ }^{(46)}$. A study reported that SARS-CoV-2 binds to placental receptors ${ }^{(24)}$, so placental analysis through PCR and anatomopathological test are indicated in cases of infected mothers.

Sample collection for PCR test with neonates from infected mothers was the most frequent method to detect possible VT, in agreement with other studies $(35-37,40,42,44)$. The absence of consensus on the specimens collected to assess potential VT is considered a limitation of all studies presented so far.

PCR is the most reliable diagnostic method for COVID-19 detection, with $98.6 \%$ sensitivity. It can show positive results from the first day of symptom, with a peak in the first week. False negatives are due to inadequate timing of collection (before or after the period described) and false positives are due to technical errors in sample collection or contamination ${ }^{(47)}$. IgM antibodies are produced two weeks after infection, decline titer in the fifth week and disappear from blood serum about seven weeks after infection, when IgG is activated. It has a $51.9 \%$ sensitivity and $95 \%$ specificity. Antibodies can be positive for other coronaviruses, resulting in a false positive, and reliability depends on the quality of the tests. Thus, an association of tests is recommended for the diagnosis. The authors highlight that the time course of PCR positivity and seroconversion may vary in neonates and children, and asymptomatic patients may not be diagnosed ${ }^{(47)}$.

A low prevalence of neonatal SARS-CoV- 2 infection was found in our analysis of the cases. This behavior is similar to that of other respiratory infections detected by viral RNA panel (SARS-CoV, MERS-CoV, parainfluenza, metapneumovirus, respiratory syncytial virus, and influenza) during pregnancy, which showed low $\mathrm{VT}^{(48)}$. Vertical transmission could not be confirmed in these cases, as there was no diagnostic confirmation in all specimens, so it could be considered a HAl. Most studies did not show evidence of VT of SARS-CoV-2 to date $36-37,39,41-42,44-45)$.

The rate of prematurity showed a wide variation, similar to that of other studies, which ranged from $18.9 \%$ to $66 \%$ of births ${ }^{(36-38,41,44-45)}$. A high prevalence of premature births can be explained by the condition of maternal pneumonia, which compromises placental flow ${ }^{(41)}$.

Similar to the rate of prematurity, the rate of neonatal ICU hospitalization varied significantly. A study pointed out neonatal ICU hospitalization in $8 \%$ of births of neonates whose mothers had COVID-19 infection ${ }^{(37)}$. Due to the results of increased rates of prematurity and a high rate of neonatal ICU occupancy in the
United Kingdom, where estimates indicate $80 \%$ of the population was infected by SARS-CoV-2, newborns are immediately separated from the mother until the PCR result ${ }^{(39)}$.

In order to avoid possible postpartum contamination, it is recommended to perform immediate clamping ${ }^{(3,32)}$ or timely clamping of the umbilical cord ${ }^{(33,49)}$, avoid contact between mother and newborn after birth, and assess the possibility of breastfeeding in mothers with mild symptoms, provided they wear a mask and use frequent hand hygiene. Breastfeeding is not recommended for mothers with severe symptoms of the disease, but milking should be encouraged to start and maintain breastfeeding after the infection is resolved ${ }^{(3,32-33,49)}$. Removed milk can be offered to the newborn, as long as the biological safety criteria are fulfilled (mothers wearing a mask and using rigorous hand hygiene) ${ }^{(50)}$.

Regarding neonatal deaths, the prevalence described in the literature varies from 0 to $7 \%{ }^{(36-42)}$, but it was not possible to determine the association with COVID-19, since all cases of death were related to prematurity.

Of note, most infections reported in the studies occurred in the third trimester of pregnancy ${ }^{(35,39,41-42)}$, which makes it difficult to clarify whether COVID-19 could be a potential cause of abortion ${ }^{(24)}$.

Although there is no evidence about VT of SARS-CoV-2, knowledge about the infection is still very limited and the risk factors have not been fully explained. The following questions are highlighted as aspects to be explored in future studies ${ }^{(51)}$ : Can the moment (gestational age) of viral exposure influence the obstetric outcomes? What are the effects of maternal treatments on the fetus? What treatments are recommended during pregnancy? What is the immune response of the pregnant woman and the fetus to different types of treatments? Do preexisting clinical conditions increase or predispose pregnant women to COVID-19 infection?

Due to the limitations of the studies and considering it is a theme involving several questions still to be answered, it is extremely important to monitor the cases and new studies are conducted, so that better evidence can support clinical practice. The details of the cases and diagnostic, and temporal, tracing in the studies should contribute to advances in the discussion aboutVT of the SARS-CoV-2.

Evidence found to date does not prove VT and strongly recommends the adoption of rigorous preventive hygiene measures by professionals and mothers to avoid the risk of neonatal infection.

\section{Study limitations}

Because it is a new disease and studies on the subject are still incipient, articles with a moderate risk of bias were included in this analysis. No standardization of diagnostic methods was observed in the studies. In addition, with a rapid literature update and an increase in the number of cases, divergent results may appear on the subject.

\section{Contributions to nursing and health care fields}

Learning about the VT profile based on evidence can support conducts for clinical practice. In view of the epidemiological scenario worldwide, this review is essential since, based on a literature mapping, it can support the development of preventive measures and adjustments to nursing care; besides, it can act as a starting point for new studies on the theme. 


\section{CONCLUSION}

Our analysis found 15 studies that evaluated cases of pregnant women with COVID-19 and their outcomes. SARS-CoV-2 infection was detected in $4.1 \%$ of neonates, but the infection cannot be concluded as vertical transmission due to the presence of factors influencing the transmission, such as contact with the mother or health professionals.

\section{FUNDING}

National Council for Scientific and Technological Development - CNPq. MCTIC/CNPq/FNDCT/MS/SCTIE/Decit protocol no. 07/2020 Research to cope with COVID-19, its consequences and other severe acute respiratory syndromes - with the title "Impacto da COVID-19 na gestação, parto e puerpério: scoping review"(Impact of COVID-19 on pregnancy, childbirth and postpartum period scoping review).

\section{REFERENCES}

1. World Health Organization (WHO). WHO coronavirus disease (COVID-19) dashboard [Internet]. Geneve: WHO; 2020 [cited 2020 Oct 8]. Available from: https://covid19.who.int/

2. Choi KR, Jeffers KS, Logsdon M. Nursing and the novel coronavirus risks and responsibilities in a global outbreak. J Adv Nurs. 2020;76(7):1486-7. https://doi.org/10.111/jan.14369

3. Poon LC, Yang H, Kapur A, Melamed N, Dao B, Divakar H, et al. Global interim guidance on coronavirus disease 2019 (COVID-19) during pregnancy and puerperium from FIGO and allied partners: information for healthcare professionals. Int J Gynaecol Obstet. 2020;149(3):27386. https://doi.org/10.1002/ijgo.1356

4. Ministério da Saúde (BR). Fluxo de manejo clínico de gestantes na atenção especializada [Internet]. Brasília, DF: Ministério da Saúde; 2020 [cited 2020 Oct 18]. Available from: https://portalarquivos.saude.gov.br/images/pdf/2020/marco/25/Fluxo-de-manejo-cl--nico-de-gestantes.pdf

5. Li N, Han L, Peng M, Lv Y, Ouyang Y, Liu K, et al. Maternal and neonatal outcomes of pregnant women with COVID-19 pneumonia: a casecontrol study. Clin Infect Dis. 2020;ciaa352. https://doi.org/10.1093/cid/ciaa352

6. Maia MM, Lage EM, Moreira BC, Deus EA, Faria JG, Pinto JA, et al. [Prevalence of congenital and perinatal infection in HIV positive pregnant in infection in HIV positive pregnant in Belo Horizonte metropolitan region]. RBGO. 2015;37(9):421-7. https://doi.org/10.1590/SO100720320150005355. Portuguese.

7. Martinez J, Santiago MR, Souza DA, Silva GE, Chahud F, Quintana SM, et al. [The role of the placenta in the vertical transmission of HIV-1]. Medicina. 2016;49(1):80-5. https://doi.org/10.11606/issn.2176-7262.v49i1p80-85. Portuguese.

8. Neu N, Duchan J, Zacharian P. TORCH infections. Clin Perinatol. 2015;42(1):77-103, viii. https://doi.org/10.1016/j.clp.2014.11.001

9. Colquhoun HL, Levac D, O'Brien KK, Straus S, Tricco AC, Perrier L, et al. Scoping reviews: time for clarity in definition, methods, and reporting J Clin Epidemiol. 2014;67(12):1291-4. https://doi.org/10.1016/j.jclinepi.2014.03.013

10. Peters MD, Godfrey CM, Khalil H, Mclnerney P, Parker D, Soares CB. Guidance for conducting systematic scoping reviews. Int J Evid Based Healthc. 2015;13(3):141-6. https://doi.org/10.1097/XEB.0000000000000050

11. Tricco AC, Lillie E, Zarin W, O'Brien KK, Colquhoun HL, Levac D, et al. PRISMA extension for scoping reviews (PRISMA-ScR): checklist and explanation. Ann Intern Med. 2018;169(7):467-73. https://doi.org/10.7326/M18-0850

12. Lockwood C, Tricco AC. Preparing scoping reviews for publication using methodological guides and reporting standards. Nurs Healh Sci. 2020;22(1):1-4. https://doi.org/10.1111/nhs.12673

13. Ursi ES, Galvão CM. Perioperative prevention of skin injury: an integrative literature review. Rev Latino-Am Enfermagem. 2006;14(1):124-31. https://doi.org/10.1590/S0104-11692006000100017

14. Melnyk BM, Fineout-Overholt E. Making the case for evidence-based practice. In: Melnyk BM, Fineout-Overholt E, (Eds.). Evidence-based practice in nursing and healthcare: a guide to best practice. Philadelphia: Lippincott Williams and Wilkins; 2005. p. 3-24.

15. Joanna Briggs Institute (JBI). 2014 Reviewers' Manual [Internet]. Adelaide: The University of Adelaide; 2020 [cited 2020 Oct 8]. Available from: https://nursing.Isuhsc.edu/JBI/docs/ReviewersManuals/ReviewersManual.pdf

16. Polit DF, Beck CT. Fundamentos de pesquisa em enfermagem: avaliação de evidências para a prática de enfermagem. 7. ed. Porto Alegre: Artmed; 2016.

17. Ferrazzi E, Frigerio L, Savasi V, Vergani P, Prefumo F, Barresi S, et al. Vaginal delivery in SARS-CoV-2 infected pregnant women in Northern Italy: a retrospective analysis. BJOG. 2020. https://doi.org/10.1111/1471-0528.16278

18. Yan J, Guo J, Fan C, Juan J, Yu X, Li J, et al. Coronavirus disease 2019 (COVID-19) in pregnant women: a report based on 116 cases. Am J Obstet Gynecol. 2020;223(1):111.e1-111.e14. https://doi.org/10.1016/j.ajog.2020.04.014

19. Lu D, Sang L, Du S, Li T, Chang Y, Yang XA. Asymptomatic COVID-19 infection in late pregnancy indicated no vertical transmission. J Med Virol. 2020:92:1660-4. https://doi.org/10.1002/jmv.25927

20. Peng Z, Wang J, Mo Y, Duan W, Xiang G, Yi M, et al. Unlikely SARS-CoV-2 vertical transmission from mother to child: a case report. J Infect Public Health. 2020;13(5):818-20. https://doi.org/10.1016/j.jiph.2020.04.004 
21. Alzamora MC, Paredes T, Caceres D, Webb CM, Valdez LM, La Rosa M. Severe COVID-19 during pregnancy and possible vertical transmission. Am J Perinatol. 2020;37(8):861-5. https://doi.org/10.1055/s-0040-1710050

22. Yang P, Wang X, Liu P, Wei C, He B, Zheng J, et al. Clinical characteristics and risk assessment of newborns born to mothers with COVID-19. J Clin Virol. 2020;127:104356. https://doi.org/10.1016/j.jcv.2020.104.356

23. Liu W, Wang J, Li W, Zhou Z, Liu S, Rong Z. Clinical characteristics of 19 neonates born to mothers with COVID-19. Front Med. 2020;13:1-6. https://doi.org/10.1007/s11684-020-0772-y

24. Li M, Chen L, Zhang J, Xiong C, Li X. The SARS-CoV-2 receptor ACE2 expression of maternal-fetal interface and fetal organs by single-cell transcription study. PLoS ONE. 2020;15(4):e0230295. https://doi.org/10.1371/jounal.pone.023095

25. Zhang ZJ, Yu XJ, Fu T, Liu Y, Jiang Y, Yang BX, et al. Novel coronavirus infection in newborn babies under 28 days in China. Eur Respir J. 2020;55(6):2000697. https://doi.org/10.1183/13993003.00697-2020

26. Chen Y, Peng H, Wang L, Zhao Y, Zeng L, Gao H, et al. Infants born to mothers with a new coronavirus (COVID-19). Front Ped. $2020 ; 8: 104$. https://doi.org/10.3389/fped.2020.00104

27. Kalafat E, Yaprak E, Cinar G, Varli B, Ozisik S, Uzun C, et al. Lung ultrasound and computed tomographic findings in pregnant woman with COVID-19. Ultrasound Obstet Gynecol. 2020;55(6):835-7. https://doi.org/10.1002/uog.22034

28. Fan C, Lei C, Fang C, Li C, Wang M, Liu Y, et al. Perinatal transmission of COVID-19 associated SARS-CoV-2: should we worry? Clin Infect Dis. 2020;ciaa226. https://doi.org/10.1093/cid/ciaa226

29. Wang S, Guo L, Chen L, Liu W, Cao Y, Yang J, et al. A case report of neonatal COVID-19 infection in China. Clin Infect Dis. 2020 ;ciaa 225. https://doi.org/10.1093/cid/ciaa225

30. Zhu H, Wang L, Fang C, Peng S, Zhang L, Chang G, et al. Clinical analysis of 10 neonates born to mothers with $2019 \mathrm{n}$-Cov pneumonia. Transl Pediatr. 2020;9(1):51-60. https://doi.org/10.21037/tp.2020.02.06

31. Chen H, Guo J, Wang C, Lou F, Yu X, Zhang W, et al. Clinical characteristics and intrauterine vertical transmission potential of COVID-19 infection in nine pregnant women: a retrospective review of medical records. Lancet. 2020;395(10226) 809-15. https://doi.org/10.1016/ S0140-6736(20)30360-3

32. Royal College of Obstetricians \& Gynaecologists (RCOG). Coronavirus infection and pregnancy [Internet]. United Kingdom: RCOG; 2020 [cited 2020 Oct 8]. Available from: rcog.org.uk/globalassets/documents/guidelines/2020-04-03-coronavirus-covid-19-infection-inpregnancy.pdf

33. Gildlof S, Savchenko J, Brune T, Joefson H. COVID-19 in pregnancy with comorbidities: more liberal testing strategy is needed. Acta Obst Gynecol Scand. 2020;99(7):948-9. https://doi.org/10.111/aogs.13862

34. Rasmussen AS, Smulian JC, Lidnicky JA, Wen TS, Jamieson DJ. Coronavirus disease 2019 (COVID-19) and pregnancy: what obstetricians need to know. Am J Obst Gynecol. 2020;222(5):415-26. https://doi.org/10.1016/j.ajog.2020.02.017

35. Cheruiyot I, Henry BM, Lippi G. Is there evidence of intra-uterine vertical transmission potential of COVI-19 infection in samples tested by quantitative RT-PCR? Eur J Obstet Gynecol. 2020;249:100-1. https://doi.org/10.1016/j.ejogrb.2020.04.034

36. Chang TH, Wu JL, Chang LY. Clinical characteristics and diagnostic challenges of pediatric COVID-19: a systematic review and meta-analysis. J Formos Med Assoc. 2020;119(5):982-9. https://doi.org/10.1016/j.jfma.2020.04.007

37. Di Marcio D, Khalil A, Saccone G, Rizzo G, Buca D, Liberati M, et al. Outcome of coronavirus spectrum infections (SARS, MERS, COVID-19) during pregnancy: a systematic review and meta-analysis. Am J Obstet Gynecol MFM. 2020;2(2):100107. https://doi.org/10.1016/jajogmfm.2020.100107

38. Panahi L, Amiri M, Pouy S. Risks of novel coronavirus disease (COVID-19) in pregnancy, a narrative review. Arch Acad Emerg Med [Internet]. 2020 [cited 2020 Oct 8];8(1):e34. Available from: https://www.ncbi.nlm.nih.gov/pmc/articles/PMC7092922/pdf/aaem-8-e34.pdf

39. Mullins E, Evans D, Viner RM, O'Brien P, Morris E. Coronavirus in pregnancy and delivery: rapid review. Ultrasound Obstet Gynecol. 2020;55(5):586-92. https://doi.org/10.1002/uog.22014

40. Zaigham M, Andersson O. Maternal and perinatal outcomes with COVID-19: a systematic review of 108 pregnancies. Acta Obstet Gynecol Scand. 2020;99(7):823-9. https://doi.org/10.1111/aogs.13867

41. Stumpfe FM, Titzmann A, Schneider MO, Stelzl P, Kehl S, Fasching PA, et al. SARS-CoV-2 infection in pregnancy: a review of the current literature and possible impact on maternal and neonatal outcome. GebFra Sci. 2020;80(4):380-90. https://doi.org/10.1055/a-1134-5951

42. Dashraath P, Wong JL, Lim MX, Lim ML, Li S, Biswas A, et al. Coronavirus disease 2019 (COVID-19) pandemic and pregnancy. Am J Obstet Ginecol. 2020;222(6):251-31. https://doi.org/10.1016/j.ajog.2020.03.021

43. Liang H, Acharya G. Novel coronavirus disease (COVID-19) in pregnancy: what clinical recommendations to follow? Acta Obstet Gynecol Scand. 2020;99:439-42. https://doi.org/10.1111/aogs.13836

44. Schwartz DA. An analysis of 38 pregnant women with of COVID-19, their newborn infants and maternal-fetal transmission of SARSCoV-2: maternal coronavirus infections and pregnancy outcomes. Arch Pathol Lab Med. 2020;144(7):799-805. https://doi.org/10.5858/ arpa.2020-0901-SA

45. Karimi-Zarchi M, Neamatzadeh H, Datgheib AS, Abbasi H, Mirjalili SR, Behforouz A, et al. Vertical transmission of coronavirus disesase 19 (COVID-19) from infected pregnant mothers to neonates: a review. Fetal Pediatr Pathol. 2020;39(3):246-50. https://doi.org/10.1080/1551381 5.2020 .1747120 
46. Trapani Jr A, Vanhoni LR, Marcolin AC, Silveira SK. Protocolo de atendimento no parto, puerpério e abortamento durante a pandemia da COVID-19. Orientações da Febrasgo [Internet]. São Paulo: Federação Brasileira das Associações de Ginecologia e Obstetrícia; 2020 [cited 2020 Oct 8]. Available from: https://portaldeboaspraticas.iff.fiocruz.br/atencao-mulher/ covid-19-orientacoes-da-febrasgo-para-avaliacao-e-tratamento-ambulatorial-de-gestantes/

47. Sethuraman N, Jeremiah SS, Ryo A. Interpreting diagnostic tests for SARS-CoV-2. JAMA. 2020;323(22):2449-51. https://doi.org/10.1001/ jama.2020.8259

48. Schwartz DA, Dhaliwal A. Infections in pregnancy with COVID-19 and other respiratory RNA virus disease are rarely, if ever transmitted to the fetus: experiences with coronaviruses, HPIV, HMPV, RSV, and Influenza. Arch Pathol Lab Med. 2020. https://doi.org/10.5858/ arpa.2020-0211-SA

49. Sociedade Brasileira de Pediatria (SBP). Recomendações para assistência ao recém-nascido na sala de parto de mãe com COVID-19 suspeita ou confirmada [Internet]. São Paulo: SBP; 2020 [cited 2020 Oct 8]. Available from: https://www.sbp.com.br/fileadmin/user_upload/22422bNAlerta-Assist_RN_SalaParto_de_mae_com_COVID-19.pdf

50. Sociedade Brasileira de Pediatria (SBP). Aleitamento materno em tempos de COVID-19 - recomendações na maternidade e após a alta [Internet]. São Paulo: SBP; 2020 [cited 2020 Oct 8]. Available from: https://www.sbp.com.br/fileadmin/user_upload/22467f-NA_-_AleitMat_ tempos_COVID-19-_na_matern_e_apos_alta.pdf

51. Scwartz DA, Graham AL. Potential maternal and infant outcomes from coronavirus 2019-n-CoV (SARS-CoV-2) infecting pregnant women: lessons from SARS, MERS and other humans coronavirus infections. Viruses. 2020;12(2):194. https://doi.org/10.3390v.12020194 